\title{
The European DISCO project: deep geological disposal of modern spent nuclear fuel
}

\author{
Dirk Bosbach $^{1}$ and Lena Z. Evins ${ }^{2}$ \\ ${ }^{1}$ Institut für Energie und Klimaforschung (IEK-6), Forschungszentrum Jülich, Jülich, Germany \\ ${ }^{2}$ Svensk Kärnbranslehantering Aktiebolag, SKB, Solna, Sweden \\ Correspondence: Dirk Bosbach (d.bosbach@fz-juelich.de) \\ Published: 10 November 2021
}

\begin{abstract}
Direct disposal of spent nuclear fuel (SNF) in a deep-mined geological repository is foreseen in various countries. Several decades of research (incl. various European projects such as SFS, NF-PRO, MICADO, REDUPP and FIRST-Nuclides) have shown that SNF shows a number of favourable properties as a waste form. Based on this background, the scientific collaborative DISCO project (2017-2021) aims to improve the understanding of the scientific basis of the safety cases for SNF under repository conditions - specifically for modern fuels. It comprises 16 project partners from eight EU countries consisting of large research institutions and small and medium enterprises (SME's), as well as an end-user group. It is supported by the European Union's Horizon 2020 Framework Programme for Research and Innovation with about 4 million euro (EU contribution). The project concept and implementation were initiated via the Exchange Forum of the Implementation of Geological Disposal - Technology Platform (IGD-TP) based on discussions among various actors, namely waste management organisations and the research community.

The specific scientific issue of the DISCO project is whether the kinetics of the SNF dissolution process are affected by the composition and characteristics of the SNF itself, with a focus on modern Cr-doped and mixed oxide (MOX) fuels, which have been developed in recent years. The effect of dopants in the fuel matrix with regard to redox reactivity of the irradiated fuel needs to be evaluated, since this may affect the dissolution behaviour of and radionuclide release from these modern fuels. The overall objectives of the DISCO project are (1) to enhance our understanding of SNF matrix dissolution under conditions representative of failed containers in reducing repository environments and (2) to assess whether novel types of fuel (MOX, doped fuels) behave in a similar manner to conventional fuels. Experimental and modelling tasks have been defined to achieve the project objectives.

The expected knowledge gain is essential for waste management organisations and will provide new insights into factors affecting their safety cases as fuel systems have evolved.
\end{abstract}

Kurzfassung. In mehreren Ländern ist die direkte Entsorgung von abgebranntem Kernbrennstoff (SNF) in einem geologischen Tiefenlager vorgesehen. Mehrere Jahrzehnte der Forschung (u. a. im Rahmen verschiedener europäischer Projekte wie SFS, NF-PRO, MICADO, REDUPP und FIRST-Nuclides) haben gezeigt, dass SNF als Abfallform eine Reihe von günstigen Eigenschaften aufweist. Vor diesem Hintergrund zielt das wissenschaftliche Verbundprojekt DISCO (2017-2021) darauf ab, das Verständnis der wissenschaftlichen Grundlagen für die Sicherheitsnachweise von SNF unter Endlagerbedingungen zu verbessern - insbesondere für moderne Brennstoffe. Es umfasst 16 Projektpartner aus 8 EU-Ländern, darunter große Forschungseinrichtungen und kleine und mittlere Unternehmen (KMU) sowie eine Endnutzergruppe. Es wird durch das Rahmenprogramm Horizon 2020 für Forschung und Innovation der Europäischen Union mit etwa 4 Millionen Euro (EU-Beitrag) unterstützt. Das Projektkonzept und die Umsetzung wurden über das Austauschforum der Technologieplattform zur Umsetzung der geologischen Endlagerung (IGD-TP) auf der Grundlage von Diskussionen zwischen verschiedenen Akteuren, insbesondere der Abfallwirtschaft und aus der Forschung, initiiert.

Die spezifische wissenschaftliche Frage des DISCO-Projekts ist, ob die Kinetik des SNF-Auflösungsprozesses durch die Zusammensetzung und die Eigenschaften des SNF selbst beeinflusst wird, wobei der Schwerpunkt 
auf modernen Cr-dotierten und MOX-Brennstoffen liegt, die in den letzten Jahren entwickelt wurden. Die Auswirkungen von Dotierstoffen in der Brennstoffmatrix auf die Redoxreaktivität des abgebrannten Brennstoffs müssen bewertet werden, da dies das Auflösungsverhalten und die Freisetzung von Radionukliden aus diesen modernen Brennstoffen beeinflussen kann. Die allgemeinen Ziele des DISCO-Projekts sind (1) die Verbesserung unseres Verständnisses der Auflösung der SNF-Matrix unter reduzierenden Bedingungen, die für Behälterversagen repräsentativ sind, und (2) die Beurteilung, ob sich neuartige Brennstoffe (MOX, dotierte Brennstoffe) ähnlich verhalten wie herkömmliche Brennstoffe. Um die Projektziele zu erreichen, wurden experimentelle und modelltechnische Aufgaben definiert.

Der erwartete Erkenntnisgewinn ist für die Entsorgungsunternehmen von wesentlicher Bedeutung und wird neue Erkenntnisse über die Faktoren liefern, die sich auf den Sicherheitsnachweis auswirken, da sich die Brennstoffsysteme weiterentwickelt haben.

Financial support. This research has been supported by the European Commission, Horizon 2020 Framework Programme (DISCO (grant no. 755443)). 